\title{
Arsenic accumulation by Pseudomonas stutzeri and its response to some thiol chelators
}

\author{
D. N. Joshi $\cdot$ J. S. Patel $\cdot$ S. J. S. Flora \\ K. Kalia
}

Received: 5 March 2008/Accepted: 12 May 2008/Published online: 4 July 2008

(c) The Japanese Society for Hygiene 2008

\begin{abstract}
Objective The aim of this study is to examine arsenic accumulation by Pseudomonas stutzeri and its response to some thiol chelators, DMPS and MiADMSA.

Methods Determination of arsenic accumulation by Pseudomonas sp. was carried out using an atomic absorption spectrophotometer, a TEM and an EDAX. Arsenate reductase enzyme assay was carried out from a cell-free extract of Pseudomonas sp. The effect of chelating agents on arsenite accumulation was analyzed. Total cellular proteins were analyzed using 1-D SDS-PAGE.

Results Pseudomonas sp. exhibited a maximum accumulation of $4 \mathrm{mg} \mathrm{As} \mathrm{g}^{-1}$ (dry weight). TEM and EDAX analysis showed the presence of As-containing electrondense particles inside the cells. Data on arsenate reductase enzyme kinetics yielded a $K_{\mathrm{m}}$ of $0.40 \mathrm{mM}$ for arsenate and a $V_{\max }$ of $5,952 \mu \mathrm{mol}$ arsenate reduced per minute per milligram of protein. The chelating agents MiADMSA and DMPS were found to reduce the arsenic accumulation by 60 and $35 \%$, respectively, whereas the presence of both chelating agents in medium containing cells pretreated with arsenite reduced it by up to $90 \%$. The total protein profile of the cellular extract, obtained by 1-D SDS-PAGE, indicated five upregulated proteins, and three of these proteins
\end{abstract}

D. N. Joshi · J. S. Patel · K. Kalia ( $₫)$

Laboratory of Biochemistry, B.R.D. School of Biosciences,

Sardar Patel University, Vallabh Vidyanagar 388 120,

Gujarat, India

e-mail: kirankalia_in@yahoo.com

\section{S. J. S. Flora}

Division of Pharmacology and Toxicology,

Defence Research and Development Establishment,

Jhansi Road, Gwalior 474 002, Madhya Pradesh, India exhibited differential expression when the cells were grown with MiADMSA and DMPS.

Conclusion This study shows a new approach towards arsenic detoxification. A combination treatment with MiADMSA and DMPS may be useful for removing intracellular arsenic. The proteins that were found to be induced in this study may play an important role in the extrusion of arsenic from the cells, and this requires further characterization.

Keywords Arsenic bioaccumulation .

Arsenate reductase $\cdot$ Chelating agent $\cdot$ Arsenic removal . Arsenic-induced protein/s

\section{Introduction}

The metalloid arsenic (As) is a member of group $\mathrm{V}$ of the periodic table and is thus classified as a heavy metal [1]. Although arsenic is generally toxic to life, it has been demonstrated that microorganisms can use arsenic compounds as electron donors or electron acceptors, and that they can possess arsenic detoxification mechanisms [2-5]. Arsenic occurs in nature in four oxidation states $(+5,+3,0$ and -3$)$, with pentavalent arsenate $[+5, \mathrm{As}(\mathrm{V})]$ and trivalent arsenite $[+3, \mathrm{As}(\mathrm{III})]$ being the most common forms. Both forms are toxic: arsenite disrupts sulfhydryl groups of proteins and interferes with enzyme function, whereas arsenate acts as a phosphate analog and can interfere with phosphate uptake and transport. Arsenic, like other heavy metals, cannot be destroyed once it has entered the environment [6]. Microorganisms have evolved a variety of mechanisms for coping with arsenic toxicity, including minimizing the amount of arsenic that enters the cell (e.g., through increased specificity of phosphate uptake), 
oxidizing the arsenite (through the activity of arsenite oxidase), or arsenite peroxidation with membrane lipids. Resistance to arsenic species in both Gram-positive and Gram-negative organisms results from energy-dependent efflux of either arsenate or arsenite from the cell, mediated by the ars operon [3-5]. Our earlier studies confirmed the existence of a bacterium with an arsC gene that is responsible for the conversion of As(V) to As(III) [7], which may be either extruded from the cells or sequestered in the intracellular compartment in its free form and/or in conjugation with glutathione (GSH) or other thiols. AQP7 and AQP9 conduct the transmembrane movement of the likely substrate, the neutral species $\mathrm{As}(\mathrm{OH})_{3}$, which may be considered an inorganic equivalent of glycerol [8]. On the other hand, microorganisms take up As(III) through the glyceroporin membrane protein [9]. It can be assumed that the aquaglyceroporin transport system found in mammalian cells may be similar to the transport system that facilitates arsenite uptake by bacterial cells.

Meso-2,3-dimercaptosuccinic acid (MiADMSA) and 2,3-dimercaptopropane-1-sulfonate (DMPS) have been considered promising antidotes to acute or chronic arsenic intoxication [10-11] due to the ability of their vicinal thiol groups to react with trivalent arsenicals, forming a saturated five-member heterocyclic ring [12]. Therefore, we made an attempt to study the response of thiol chelating agents on arsenic accumulation using Pseudomonas sp. as a model system, which may help to improve understanding of the role of chelating agents in the arsenic detoxification mechanism.

\section{Materials and methods}

Pseudomonas stutzeri that had been isolated and characterized in our lab, and which has the ability to grow in the presence of arsenic [7], was used for the present study. This bacterium has shown maximum tolerance levels of $50 \mathrm{mM}$ for arsenate and $0.2 \mathrm{mM}$ for arsenite, respectively. $\mathrm{Na}$ arsenate, Na meta-arsenite, NADPH, and DTT were procured from Sigma (St. Louis, MO, USA); DMPS and MiADMSA were a gift from Dr S.J.S. Flora, DRDE, Gwalior.

\section{Growth kinetics for Pseudomonas sp.}

Culture slants were made and kept at $4{ }^{\circ} \mathrm{C}$. The bacteria were grown at $37{ }^{\circ} \mathrm{C}$ in nutrient broth medium with continuous shaking at $110 \mathrm{rpm}$ in the orbital shaker for all of the given conditions (control, arsenic stress). Cells were harvested by centrifugation $(5,000 \times g$ for $10 \mathrm{~min})$ at different time intervals during the lag, log and the stationary phases. Optical density was measured after different time intervals at $600 \mathrm{~nm}$ using a Cary (Varian, Palo Alto, CA, USA) $50 \mathrm{UV}$-visible spectrophotometer. The growth rate constant $(k)$ for the log phase of growth was determined by plotting the $\log _{10}$ of the optical density against time [12]. Experiments were performed in triplicate and repeated three times.

Determination of arsenic accumulation by Pseudomonas sp.

Cells were harvested by centrifugation $(5,000 \times g$ for $10 \mathrm{~min}$ ) and the $\mathrm{pH}$ of the supernatant was measured. The cell pellets were washed 2-3 times with normal saline, dried, and then used in the measurements of arsenic accumulation. One-milliliter samples were taken at various time intervals for cell mass determination and for arsenic quantification.

Arsenate reductase enzyme assay

Pseudomonas sp. bacteria were grown to mid-log phase in $200 \mathrm{ml}$ of $\mathrm{NB}$ medium supplemented with $50 \mathrm{mM}$ of arsenate, harvested by centrifugation for $10 \mathrm{~min}$ at $5,000 \mathrm{rpm}$, and washed twice in $25 \mathrm{ml}$ reaction buffer (10 mM Tris, pH 7.5, with $1 \mathrm{mM} \mathrm{Na} 2$ EDTA and $1 \mathrm{mM}$ $\mathrm{MgCl}_{2}$ ). The cells were resuspended in $5 \mathrm{ml}$ of reaction buffer, disrupted by sonication and cell-free extract was prepared by centrifugation at $5,000 \times g$ for $10 \mathrm{~min}$ at $4{ }^{\circ} \mathrm{C}$. Arsenate reductase activity was measured using a method based on NADPH oxidation [13]. The reaction was initiated at $37{ }^{\circ} \mathrm{C}$ by mixing $50 \mu$ of cell-free crude extract in $820 \mu \mathrm{l}$ of reaction buffer, $20 \mu \mathrm{l}$ of $10 \mathrm{mM}$ DTT (final concentration $300 \mu \mathrm{M}$ ), and $50 \mu \mathrm{l}$ of $3 \mathrm{mM}$ NADPH (final concentration $0.15 \mathrm{mM}$ ). Arsenate concentrations of 200, 500 and $1 \mathrm{mM}$ were assayed along with "no arsenic" for controls. Absorbance decreases at $340 \mathrm{~nm}$ were recorded as NADPH oxidization coupled to the reduction of arsenate to arsenite. Enzyme activity was calculated using a molar extinction coefficient of $6.2 \times 10^{3}$ for $\mathrm{NADP}^{+}$. The endogenous NADPH oxidation rate was subtracted from the arsenate-induced NADPH oxidation.

\section{TEM and EDAX analysis}

Pseudomonas sp. bacteria grown without (control) and with (experimental) $50 \mathrm{mM}$ sodium arsenate were harvested and fixed for $2 \mathrm{~h}$ at room temperature in $4 \%$ glutaraldehyde and then washed four times at the stationary phase in $0.1 \mathrm{M}$ phosphate buffer $\mathrm{pH}$ (7.2). Pre-embedding of bacterial cells was done in $4 \%$ agar, and small pieces $\left(1-2 \mathrm{~mm}^{2}\right)$ were cut from solidified agar blocks. These pieces were fixed overnight at $4{ }^{\circ} \mathrm{C}$ in $2 \%$ osmium tetroxide $\left(\mathrm{OsO}_{4}\right)$ in phosphate buffer before being 
dehydrated with acetone and embedded in polyepoxy resin. Ultrathin sections were cut with an ultramicrotome (Reichert OMU3, Vienna, Austria) equipped with a diamond knife and then stained with uranyl acetate and lead citrate as contrasting agents. The sections were mounted on copper grids. Micrographs of both control (without arsenate) and experimental cells (treated with arsenate) were taken with a 2000FX II transmission electron microscope (TEM) (JEOL, Eching, Germany), operating at $200 \mathrm{kV}$. Energydispersive X-ray analysis (EDAX) of the cell pellets was performed with a Philips (Eindhoven, The Netherlands) XL-30 electron microscope equipped with an ESEM-TMP EDAX microanalysis system (Philips).

Use of chelating agents to remove arsenite from Pseudomonas sp.

Bacterial cells were grown in a nutrient broth medium containing $0.2 \mathrm{mM}$ arsenite. The cells were harvested at different time intervals during the lag, $\log$ and stationary phases by centrifugation at $5,000 \times g$ for $10 \mathrm{~min}$ at $4{ }^{\circ} \mathrm{C}$ and transferred into a medium containing the chelating agents MiADMSA $\left(50 \mu \mathrm{g} 100 \mathrm{ml}^{-1}\right)$ and DMPS $\left(50 \mu \mathrm{g} 100 \mathrm{ml}^{-1}\right)$ either alone or in combination, and allowed to grow for $4 \mathrm{~h}$ as follows:

- Group 1: Arsenic control (bacterial cells grown with $0.2 \mathrm{mM}$ arsenite prepared in nutrient broth medium and transferred into $\mathrm{N}$ saline for $4 \mathrm{~h}$ )

- Group 2: Cells grown with $0.2 \mathrm{mM}$ arsenite and then transferred into a medium containing DMPS $\left(0.5 \mu \mathrm{g} \mathrm{ml}^{-1}\right)$ for $4 \mathrm{~h}$

- Group 3: Cells grown with $0.2 \mathrm{mM}$ arsenite and then transferred into a medium containing MiADMSA $\left(0.5 \mu \mathrm{g} \mathrm{ml}^{-1}\right)$ for $4 \mathrm{~h}$.

- Group 4: Cells grown with $0.2 \mathrm{mM}$ arsenite and then transferred into a medium containing MiADMSA and DMPS $\left(0.5 \mu \mathrm{g} \mathrm{ml}^{-1}\right)$ for $4 \mathrm{~h}$.

- Group 5: Control (bacterial cells grown in nutrient broth medium)

One-milliliter samples were taken at various time points for cell mass determinations and for arsenic analysis, while
$5 \mathrm{ml}$ samples were taken after $24 \mathrm{~h}$ during the mid-log phase to evaluate the cellular protein profiles of all of the groups. SDS gel electrophoresis was performed as per the method of Laemmli [14].

\section{Metal estimation}

The arsenic concentrations in all of the samples were measured using an atomic absorption spectrophotometer with an autosampler (AS-72, AAS PerkinElmer, Norwalk, CT, USA) and a graphite furnace (MHS) (Analyst 100, AAS PerkinElmer) following wet acid digestion of the bacterial cells. Pellets were dried at $90-100{ }^{\circ} \mathrm{C}$ to constant weight and digested with concentrated nitric acid using a microwave digestion system (Multiwave 3000, Anton Paar, Austria, Europe). Samples were brought to a constant volume before analysis.

\section{Results}

Effect of arsenic on the growth kinetics of Pseudomonas sp.

Growth comparisons of the cells grown in arsenic-free media and arsenic-containing media revealed an approximately twofold decrease in growth following arsenic treatment as compared to the cells grown in arsenic-free media. The growth rate calculated in the absence of arsenic was $0.76 \mathrm{~h}^{-1}$ (a doubling time of $1.30 \mathrm{~h}$ ), in the presence of arsenate it was $0.43 \mathrm{~h}^{-1}$ (a doubling time of $2.32 \mathrm{~h}$ ), and in the presence of arsenite it was $0.33 \mathrm{~h}^{-1}$ (a doubling time of $3.30 \mathrm{~h}$ ) at the maximum tolerance limit of the bacteria, resulting in 43 and $56 \%$ reductions in the cellular growth of the bacterial isolate by arsenate and arsenite, respectively. The data thus suggests a 1.3-fold decrease in cellular growth due to the higher toxicity of arsenite compared to arsenate (Fig. 1A,B). The $\mathrm{pH}$ of the extracellular medium was found to increase gradually from 7.2 to 9.2 from the lag to the stationary phase due to the arsenate in the medium (Fig. 1A), while the $\mathrm{pH}$ was only slightly increased, from 7.2 to 7.6 , by arsenite (Fig. 1B).
Fig. 1A-B Growth of Pseudomonas sp. in (A) the presence of $50 \mathrm{mM}$ arsenate and (B) the presence of $0.2 \mathrm{mM}$ arsenite. The change in $\mathrm{OD}_{600}$ versus extracellular $\mathrm{pH}$ over $48 \mathrm{~h}$ is shown. Values are mean $\pm \operatorname{SE}(n=9)$
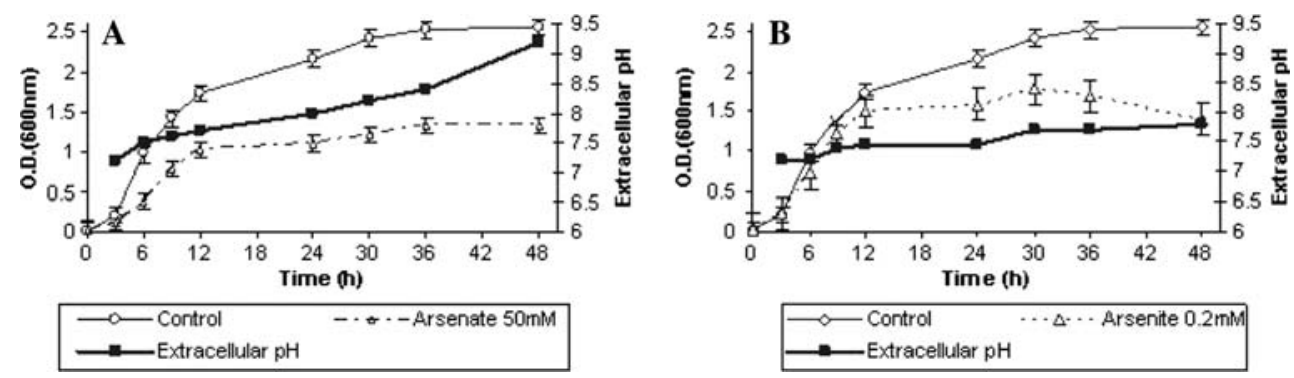


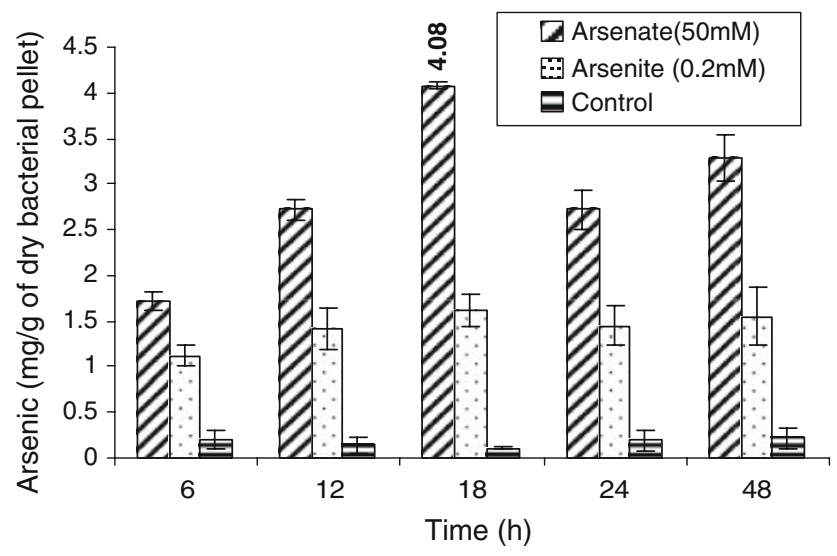

Fig. 2 Bioaccumulation of arsenic by Pseudomonas sp. Values are mean $\pm \operatorname{SE}(n=9)$

Determination of the accumulation of arsenic by the bacterial isolate

Arsenic accumulation by cells grown with arsenate was found to be 1.6 times higher than that for cells grown with arsenite during the lag phase, whereas cells grown with arsenate exhibited 2-3 times higher arsenic accumulations during different growth phases than cells grown with arsenite (Fig. 2). The maximum arsenic accumulation of $4.08 \pm 0.08 \mathrm{mg} \mathrm{As} \mathrm{g}^{-1}$ in the dry pellets of Pseudomonas sp. was found during the mid-log phase; after this, the organism started to produce an efflux of the intracellular arsenic into the extracellular environment.

\section{Arsenate reductase activity}

The arsenate reductase activity was analyzed during the mid-log phase of growth, which corresponded to the maximum accumulation of arsenic by the cells before the organism started to produce an efflux of intracellular arsenic. The data on the enzyme kinetics, calculated using a Lineweaver-Burk plot, showed a $K_{\mathrm{m}}$ of $0.40 \mathrm{mM}$ for arsenate and a $V_{\max }$ of $5,952 \mu \mathrm{mol}$ arsenate reduced $\min ^{-1} \mathrm{mg}^{-1}$ protein for the arsenate reductase of Pseudomonas sp. (Fig. 3). Under these conditions, the cellular concentration of arsenic was found to $0.01 \mathrm{mM}$, whereas the $K_{\mathrm{m}}$ value for arsenate of $0.40 \mathrm{mM}$ indicates that the cellular concentration is too low in cells during the mid-log phase, and so the arsenate reductase is less active, leading to insufficient conversion of arsenate to arsenite, which may result in arsenate accumulation by the cells.

\section{TEM and EDAX analysis}

Transmission electron microscopy was used to localize the arsenic that was accumulated by Pseudomonas sp.

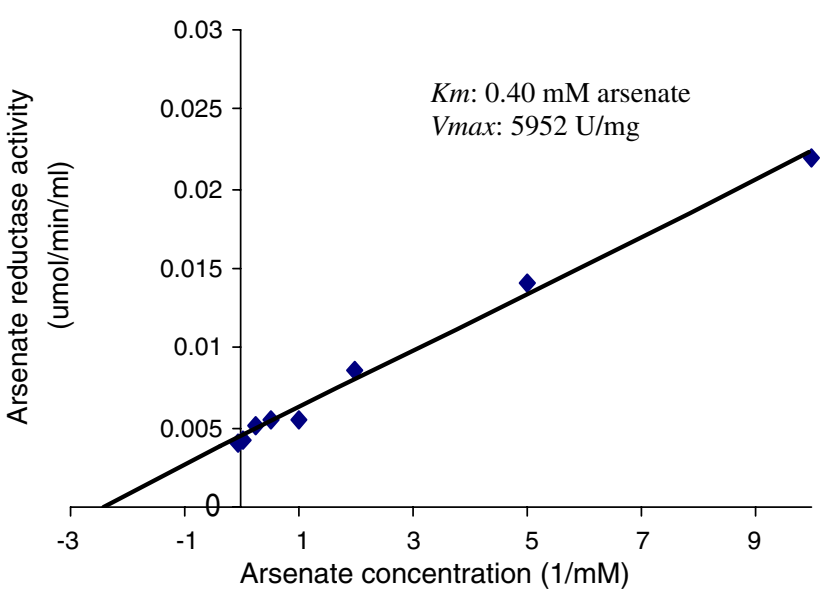

Fig. 3 Determination of $K_{\mathrm{m}}$ and $V_{\max }$ for the arsenate reductase from Pseudomonas sp. A Lineweaver-Burk plot was used to depict the dependence of the arsenate reductase activity on the arsenate concentration

cells. Electron-dense deposits were found in the cytoplasm of the cells grown in the presence of $50 \mathrm{mM}$ arsenate. It was also possible to observe that some of the arsenic accumulated in the periplasm (Fig. 4A,B), which did not occur in the cells grown without the metalloid (Fig. 4C,D). The presence of arsenic in the electron-dense areas was confirmed by EDX analysis (Fig. 4E,F), thus suggesting cytoplasmic accumulation of the metalloid by the Pseudomonas sp.

Use of chelating agents to remove arsenite from bacterial cells

Figure 5 shows the effect of MiADMSA and DMPS used individually and in combination on arsenic accumulation by Pseudomonas sp. previously grown in arsenite-containing medium. The presence of MiADMSA and DMPS in the medium was found to reduce the arsenic accumulation by cells pre-grown in arsenite-containing medium up to different growth stages. The highest reduction was observed when the cells were transferred into the medium with both of the chelating agents used in combination. Arsenic accumulation was significantly reduced (by 15 , 75 and 93\%) in cells in the lag phase when DMPS, MiADMSA and a combination of them, respectively, were applied, as compared to cells grown in arsenitecontaining media. Cells in the initial $\log$ phase reduced their arsenic accumulation by up to 30 and $37 \%$ when DMPS and MiADMSA were applied, respectively, and a reduction of $90 \%$ was observed in the presence of both of the chelating agents. The use of MiADMSA and DMPS individually was found to be effective at reducing arsenic accumulation by 65 and $61 \%$, respectively, in cells in the mid-log phase as compared to cells in the initial log 
Fig. 4A-F Transmission electron micrograph and EDAX analysis of the Pseudomonas sp. grown in the absence and presence of arsenate.

A Pseudomonas sp. grown in the absence of arsenate $(\times 15 \mathrm{~K})$,

B Pseudomonas sp. grown in the absence of arsenate $(\times 30 \mathrm{~K})$.

C Pseudomonas sp. grown in the presence of arsenate $(\times 15 \mathrm{~K})$, D Pseudomonas $\mathrm{sp}$. grown in the presence of arsenate $(\times 30 \mathrm{~K})$. E Cytoplasmic accumulation of arsenic Pseudomonas sp. when bacterial growth occurs in metal-free medium. F Cytoplasmic accumulation of arsenic in Pseudomonas sp. when bacterial growth occurs in medium with $50 \mathrm{mM}$ of arsenate
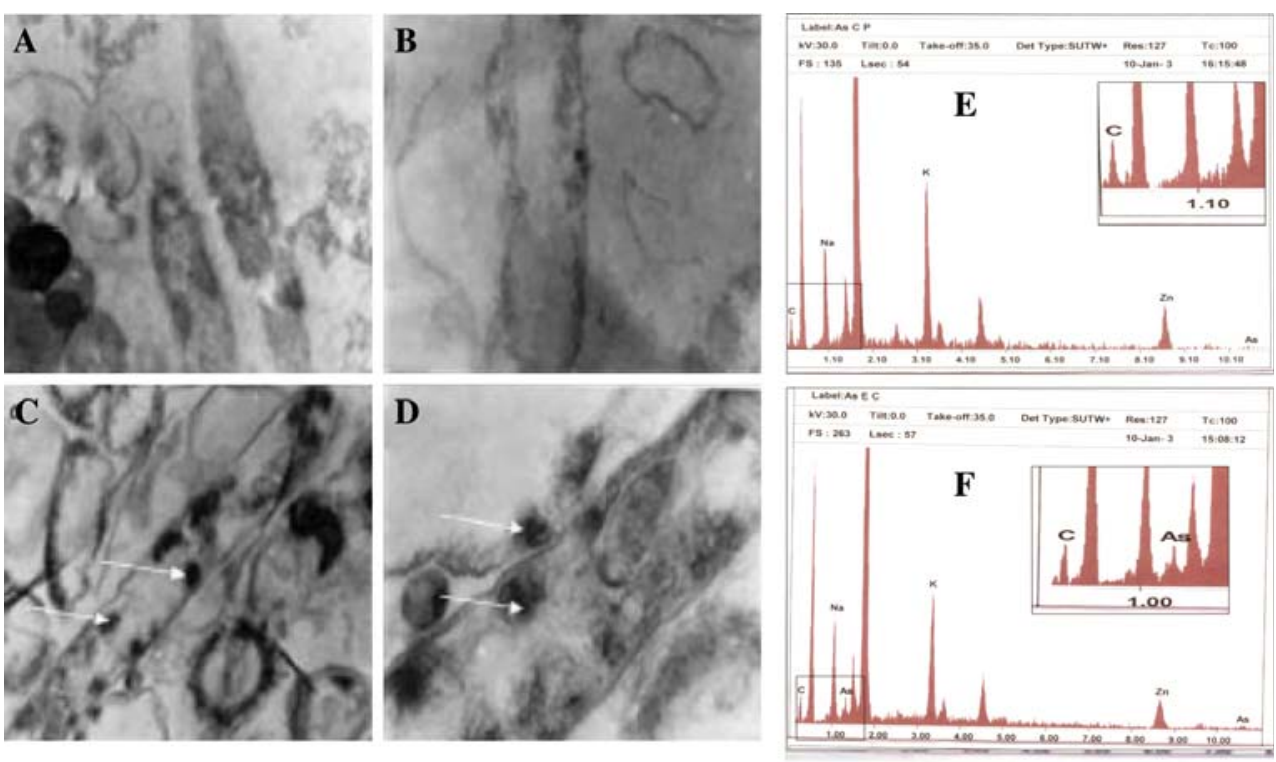



Fig. 5 Effects of MiADMSA and DMPS on Pseudomonas sp. preexposed to arsenite. Units: arsenic concentration in the bacterial cells as milligram per gram of dry weight. Values are mean $\pm \operatorname{SE}(n=9)$

phase, whereas MiADMSA was found to be more effective (an $84 \%$ reduction was observed) in cells in the late log phase compared to DMPS (for which a $50 \%$ reduction was observed). Similarly, MiADMSA showed a 78\% reduction and was found to be more effective than DMSA (45\% reduction) in cells at the stationary phase. Our results indicate that DMPS was effective at reducing arsenic accumulation (reductions of $15-60 \%$ ) in cells pregrown with arsenite up to different stages of growth, while MiADMSA was found to be more effective than DMPS at reducing arsenic accumulation (reductions of $37-84 \%$ ), although the presence of both the chelating agents yielded reductions of $81-95 \%$, indicating the synergistic effect of MiADMSA and DMPS in the removal of intracellular arsenic.
Effect of chelating agents on the cellular protein profile

The total protein profile of the cellular extract of cells grown with arsenic alone exhibited five upregulated proteins with molecular weights of 90, 52, 35, 25 and $14 \mathrm{kDa}$, indicating their roles in metal resistance, accumulation and/ or transport of arsenic, while one protein with a molecular weight of $12 \mathrm{kDa}$ showed downregulation (Fig. 6; lane 2). Two of these proteins, those of molecular weights 52 and $25 \mathrm{kDa}$, were repressed when the cells were transferred to a medium containing DMPS (Fig. 6; lane 3), and were shown to be downregulated when the cells were transferred into a medium containing MiADMSA alone or in combination with DMPS, indicating the probable role of these proteins in arsenic uptake from the medium (Fig. 6; lanes $4,5)$. The low molecular weight $12 \mathrm{kDa}$ protein which was repressed by arsenite exposure was significantly expressed in the cells transferred to the medium containing MiADMSA alone or in combination with DMPS (Fig. 6; lanes 4,5 ), indicating the role of this protein in the intracellular efflux of arsenic and thus in the reduction of arsenic accumulation.

\section{Discussion}

The effects of environmental arsenic on human health can be devastating. This aspect, together with the environmental ubiquity of arsenic, led to the evolution of arsenic defense mechanisms in every organism studied, from Escherichia coli to humans. Organisms take up $\mathrm{As}(\mathrm{V})$ via phosphate transporters and As(III) by glyceroporin membrane protein [9] or hexose transporters [15]. As(V) is then 


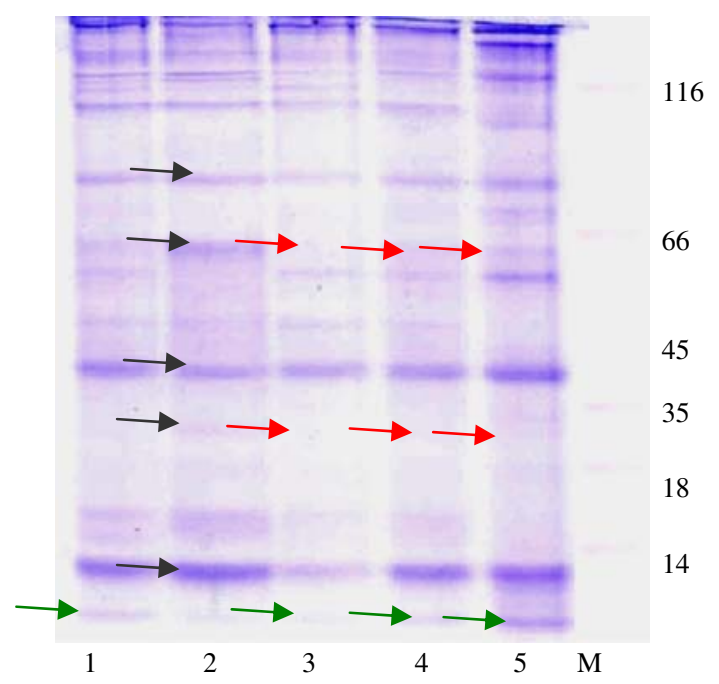

Fig. 6 Effects of the chelating agents on the cellular protein profile. Samples were harvested during the mid-log phase after $24 \mathrm{~h}$ growth and then analyzed by SDS-PAGE (12\%). The desired proteins are marked with arrows. 1, Control, 2, arsenite, 3, DMPS, 4, MiADMSA, 5 , DMPS and MiADMSA, $M$, marker

reduced to As(III), which may be either extruded from the cells, sequestered in the intracellular compartment in its free form and/or in conjugation with glutathione (GSH) or other thiols. In this study we focused on arsenic uptake by Pseudomonas sp. and its response to some conventional thiol chelating agents like DMPS and MiADMSA.

Our isolate could grow in up to $50 \mathrm{mM}$ arsenate and could maintain its character even after being grown for 3-4 generations in metal-free medium. The decrease in the growth rate in the presence of a high concentration of arsenic may be due to the association of this ion with the membrane fraction, resulting in an expanded membrane, which may increase the number of binding sites and make it less effective at transporting materials needed for growth [16]. Macy et al. [17] reported that the increase in the external $\mathrm{pH}$ to 9.4 when organisms used acetate as an electron donor was linked to arsenate reduction. A number of organisms have been isolated that use arsenic as a terminal electron acceptor in anaerobic respiration [2]. There is a decrease in growth rate under these conditions and an increase in the final $\mathrm{pH}$ of the medium from 7.2 to 9.2, suggesting that the reduction in growth caused by arsenate and the alkalization of the medium might be due to the reduction of arsenate to arsenite. The $\mathrm{pH}$ of the medium was not found to be altered when cells grown with arsenite.

Aquaglyceroporins have been shown to facilitate the uptake of As(III), including E. coli GlpF [18], S. cerevisiae Fps1p [19-20], mouse AQP7 [19], and AQP9 from rat [19] and humans [15]. It can be assumed that the aquaglyceroporin transport system found in the mammalian cells may be similar to the transport system that facilitates arsenite uptake by bacterial cells. Pseudomonas sp. exhibited a maximum arsenic accumulation of $4 \mathrm{mg} \mathrm{As} \mathrm{g}^{-1}$ in dry bacterial pellets after $18 \mathrm{~h}$ of growth when supplemented with $50 \mathrm{mM}$ arsenate, which may be due to the intracellular sequestration of arsenic. The arsenate reductase activity was found to be maximum during the mid-log phase of growth, indicating the conversion of arsenate to arsenite, which may be the mechanism driving the intracellular removal of arsenite by these cells after $18 \mathrm{~h}$ of growth. TEM and EDAX analysis showed the presence of As-containing electron-dense particles inside the cells, confirming the intracellular accumulation of the metalloid anion by Pseudomonas sp.

Sodium 2,3-dimercaptopropane sulfonate (DMPS) is another analog of BAL and is mainly distributed in the extracellular space. It can enter cells through a specific transport mechanism. No major adverse effects on humans or animals have been reported after DMPS administration [21]. The monoisoamyl ester of DMSA (MiADMSA; a C5 branched chain alkyl monoester of DMSA) has been found to be more effective than DMSA at reducing the cadmium and mercury burden [11, 22-24]. As(III), which is reduced form of $\mathrm{As}(\mathrm{V})$, may form conjugates with either glutathione (GSH) or another thiol. Cells of Pseudomonas sp. pretreated with arsenite have shown to reduce their arsenic accumulation when in the presence of DMPS and MiADMSA either individually or in combination, indicating the role of these chelators in the arsenic uptake mechanism. These chelating agents probably form complexes with the arsenic and these complexes can then be extruded from the cells, suggesting that DMPS and MiADMSA could be useful for the removal of arsenic. MiADMSA would be especially advantageous, as it possesses high reactivity toward arsenite. Chelating agents can also affect the specific transport of proteins like glyceroporin membrane protein, leading to a reduction in arsenite uptake by these cells, or it may act as a competitive inhibitor for arsenite, thus aiding in the removal of intracellular arsenic by Psudomonas sp. The ability of these bacteria to remove arsenic-chelate complexes from solution relies on the presence of specific As-chelator transporter proteins; this topic needs further characterization.

It is established that many microorganisms survive in the presence of toxic metals or metalloids by inducing the expression of an array of resistance proteins. The highly specific nature of these resistance mechanisms is the result of a cleverly designed genetic circuit that is tightly controlled by specific metalloregulatory proteins. Patel et al. [7] have recently reported on multiple physiological responses induced by arsenate stress in P. stutzeri which are not exclusively associated with the expression of classical arsenic resistance operons, indicating the probable role of these proteins in the arsenic resistance mechanism. 
The role of proteins in the mechanism of the resistance of $P$. fluorescens to heavy-metal-induced stress, such as from $\mathrm{Cu}, \mathrm{Co}$ and $\mathrm{Pb}$, was demonstrated by Sharma et al. [25]. Our results indicate differential expression when cells grown with MiADMSA and DMPS either individually or in combination, indicating the probable role of these proteins in the intracellular efflux of arsenite, which require further detailed studies.

The removal of toxic components like arsenic is of great importance, not only because of the resulting decontamination but also because this removal is important to human welfare and for maintaining ecological balance. Its high accumulation of and tolerance toward arsenic indicates that P. stutzeri could be a suitable candidate for developing bioremediation processes. The similarity between the aquaglyceroporin transport system found in bacterial cells and mammalian cells facilitating arsenite uptake suggests that MiADMSA and DMPS may be useful for the removal of intracellular arsenic, although this subject requires further exploration.

Acknowledgment The authors thank the Director of the Defence Research and Development Establishment, Government of India, Gwalior, India for financial support.

\section{References}

1. Wackett LP, Dodge AG, Ellis LB. Microbial genomics and the periodic table. Appl Environ Microbiol. 2004;70:647-55.

2. Ahmann D, Roberts AL, Krumholz LR, Morel FM. Microbe grows by reducing arsenic. Nature. 1994;371:750.

3. Cervantes C, Ji G, Ramirez JL, Silver S. Resistance to arsenic compounds in microorganisms. FEMS Microbiol Rev. 1994; 15:355-67.

4. Ji GY, Silver S. Regulation and expression of the arsenic resistance operon from Staphylococcus aureus plasmid pI258. J Bacteriol. 1992;174:3684-94.

5. Ji GY, Silver S. Reduction of arsenate to arsenite by the ArsC protein of the arsenic resistance operon of Staphylococcus aureus plasmid pI258. Proc Natl Acad Sci USA. 1992;89:9474-8.

6. Valls M, De Lorenzo V. Exploiting the genetic and biochemical capacities of bacteria for the remeidation of heavy metal pollution. FEMS Microbiol Rev. 2002;26:327-38.

7. Patel PC, Goulhen F, Botthman C, Gault AG, Charnock JM, Kalia K, et al. Arsenate detoxification in a Pseudomonas hypertolerant to arsenic. Arch Microbiol. 2007;187:171-83.

8. Rosen BP. Biochemistry of arsenic detoxification. FEBS Lett. 2002;52:986-92.
9. Mukhopadhyay R, Rosen BP, Phung T, Silver S. Microbial arsenic: from geocycles to genes and enzymes. FEMS Microbiol Rev. 2002;26:311-25.

10. Anderson O. Principles and recent developments in chelation treatment of metal intoxication. Chem Rev. 1999;99:2683-710.

11. Flora SJS, Bhattacharya R, Vijayraghvan R. Combined therapeutic potential of meso-2,3-dimercapto succinic acid and calcium dosodium edentate in the mobilization and distribution of lead in experimental lead intoxication in rats. Fundam Appl Toxicol. 1995;25:233-40.

12. Pirt SJ. Principles of microbe and cell cultivation. Oxford: Blackwell; 1975.

13. Anderson CR, Cook GM. Isolation and characterization of arsenate reducing bacteria from arsenic contaminated sites in New Zealand. Curr Microbiol. 2004;48:341-7.

14. Laemmli UK. Cleavage of structural proteins during the assembly of head of the bacteriophage T4. Nature. 1970;277:680-5.

15. Suzuki Y, Matsushita H. Interaction of metal ions and phospholipids monolayers as a biological membrane model. Ind Health. 1968;6:128-33.

16. Liu Z, Carbrey JM, Agre P, Rosen BP. Arsenic trioxide uptake by human and rat aquaglyceroporins. Biochem Biophys Res Commun. 2004;316:1178-85.

17. Macy JM, Nunan K, Hagen KD, Dixon DR, Harbour PJ, Cahill $\mathrm{M}$, et al. Chrysiogenes arsenatis gen. nov., sp. nov., a new arsenaterespiring bacterium isolated from gold mine wastewater. Int J Syst Bacteriol. 1996;46:1153-7.

18. Sanders OI, Rensing C, Kuroda M, Mitra B, Rosen BP. Antimonite is accumulated by the glycerol facilitator GlpF in Escherichia coli. J Bacteriol. 1997;179:3365-7.

19. Liu Z, Shen J, Carbrey JM, Mukhopadhyay R, Agre P, Rosen BP. Arsenite transport by mammalian aquaglyceroporins AQP7 and AQP9. Proc Natl Acad Sci USA. 2002;99:6053-8.

20. Wysocki R, Chery CC, Wawrzycka D, Van HM, Cornelis R, Thevelein JM. The glycerol channel Fps1p mediates the uptake of arsenite and antimonite in Saccharomyces cerevisiae. Mol Microbiol. 2001;40:1391-401.

21. Hurby K, Donner A. 2, 3-Dimercapto-1-propanesulphonate in heavy metal poisoning. Med Toxicol Adverse Drug Exp. 1987;2:317-23.

22. Jones MM, Singh PK, Gale GR, Smith AB, Atkins LM. Cadmium mobilization in vivo by intraperitoneal or oral administration of mono-alkyl esters of meso-2,3-dimercaptosuccinic acid. Pharmacol Toxicol. 1992;70:336-42.

23. Gale GR, Smith AB, Jones MM, Singh PK. Meso 2-3 dimercaptosuccinic acid monoalkyl esters: effects on mercury levels in mice. Toxicology. 1993;81:49-56.

24. Xu C, Holscher MA, Jones MM, Singh PK. Effect of monoisoamyl meso-2,3-dimercaptosuccinate on the pathology of acute cadmium intoxication. J Toxicol Environ Health. 1995;45:26177.

25. Sharma S, Sundaram CS, Luthra PM, Singh Y, Sirdeshmukh R, Gade WN. Role of proteins in resistance mechanism of Pseudomonas fluorescens against heavy metal induced stress with proteomics approach. J Biotechnol. 2006;126:374-82. 